\title{
Effect of Foliar Applications of Anti-Heat Stress Treatments on Yield and Fruit Quality of Balady Mandarin and their Effect on Yoghurt
}

\author{
Manal A. Zaky ${ }^{1}$ and Meranda A. Tawfek ${ }^{2}$ \\ ${ }^{I}$ Citrus Research Dept., Horticulture Research Institute (HRI), Agricultural Research Center (ARC), \\ Giza, Egypt. \\ ${ }^{2}$ Dairy Technology Research Dept., Food Technology Research Institute (FTRI), Agricultural \\ Research Center (ARC), Giza, Egypt.
}

Received: 10 Nov. 2019 / Accepted 15 Dec. 2019/ Publication date: 20 Dec. 2019

\begin{abstract}
Heat stress caused during high temperature and direct solar radiation. Subsequently, sunburn occurred and caused allot of problems, which lead to significant economic losses in Balady mandarin crop. Trees were treated with Kaolin 3\% twice, and kaolin 6\% to study the effect of kaolin as an antiheat stress on fruit quality of Balady mandarin trees during the two seasons (2016 and 2017). These treatments caused an increase in fruit production as well as fruit quality (weight, volume, diameter, and length). Also treatments caused enhancement in the chemical composition of mandarin fruits, expressed as total sugar, acidity, fibers, protein, TSS/TA ratio and TSS\%. Moreover, fruits juice from treated trees were used for preparing mandarin flavored yoghurt. The results showed that kaolin treatments improved the rheological characteristics and the total acceptability of yoghurt. From the obtained results, it is recommended to: carry out foliar application of Balady mandarin, cultivated in newly reclaimed lands with Kaolin at $6 \%$ concentration at mid-June to significantly increase fruits quality and the ability to produce mandarin flavored yoghurt, consequently increase the add value to the fruits.
\end{abstract}

Keywords: Kaolin clay, Citrus reticulate, mandarin flavored yoghurt, value addition

\section{Introduction}

Citrus production occupies the first rank among other fruits production in Egypt. Balady mandarin came in the second place after Orange where the total area is 111348 Fed., with total production of 935536 tone (according to Ministry of Agriculture and Land Reclamation/ Annual report 2017).

Balady mandarin fruits suffers from sunburn as a result of heat stress. Direct solar radiation cause fruit damages such as: splitting, rind disorders, sunburn and other fruit blemishes (Minessy et al., 1969). These disorders have a negative effect on yield and fruit quality as well as increase of unmarketable fruits and cause high losses to the growers (Verreynne and Merwe, 2011). Therefore ,foliar spraying of Kaolin-based particle films could be reduce the injured fruits percentage as well as, increase fruit weight and size (Zaky et al., 2018). Additionally, anti-heat stress substances improving fruit quality and production of fruit crops and were reducing water evaporation for several plants (Hassan and Seif, 1997; Prakassh and Ramachndran, 2000; Sophocleous, 2004; Saleh and El-Ashry Soad, 2006; Ahmad et al., 2012 and Ebrahiem Asmaa, 2012).

Moreover, foliar spraying of kaolin on apple tree led to minimizing the temperature of fruit surface, reducing sun injuries as well as improving yield and fruit quality Glenn, (2009). Kaolin foliar applications at 3 and $4 \%$ decreased leaf heat and fruit surface temperature and was more effective to control sunburned fruits of Balady mandarin trees (Ennab et al., 2017). Moreover, kaolin foliar spray was used to enhance water use efficiency and reducing the adverse effects of water deficit on pistachio and pomegranate trees (Azizi et al., 2013; El-Khawaga and Mansour 2014).

Flavor of mandarins fruits is unique and richer than that of most citrus species. It contains an antioxidant called "Quercetin" which reduces cellular death caused by oxidation and inflammation of neurons (De Ancos et al., 2017). Moreover, fruits have a high in fiber and vitamin C, K, B 6, and riboflavin percentage which in turn helps prevent atherosclerosis and heart disease and helps prevent

Corresponding Author: Manal A. Zaky, Citrus Research Dept., Horticulture Research Institute (HRI), Agricultural Research Center (ARC), Giza, Egypt.

E-Mail: manal_z_thabet@hotmail.com 
cholesterol from building up in the lining of blood vessels. Beside, low in calories and no fat or cholesterol (Abeysinghe et al., 2007).

The increasing attractiveness of mandarin juice with consumers, as well as the importance which food technology scientists attach to such juice, has led to an impressive development in this sector.

Consumption of dairy products is associated with beneficial health effects beyond their nutritional values. Due to its healthy perception, dairy products have been served as vehicles for functional food ingredients over the last 20 years, such as phytochemical and probiotics. Fermented milk products have positive health image due to the beneficial viable bacteria and yoghurt has been already recorded as a healthful product. Yoghurt contains healthy bacteria known as probiotics, which keep the digestive and immune system functioning well. It is also a good source of protein and nutrients important for bone health. Yoghurt help prevent osteoporosis, reduce the risk of high blood pressure and active cultures helps the gut (Lourens, 2001).

The main objective of this study was to examine the effect of anti-heat stress treatments as Kaolin particles fruit yield and quality of mandarin trees. Furthermore, to develop functional yoghurt of acceptable quality based on mixing yoghurt and mandarin. Value added processing of horticultural crops essentially includes activities that alter fresh fruits to produce a higher value added product for human consumption. The chemical, rheological, physical and organoleptic characteristics of mandarin and the formulated yoghurt were determined.

\section{Materials and Methods}

Kaolin clay is a naturally occurring mineral, the main constituent is kaolinite with the formula $\mathrm{Al}_{2} \mathrm{Si}_{2} \mathrm{O}_{5}(\mathrm{OH})_{4}$ (Yahaya et al., 2017). It used in the present study as anti-heating stress treatment, which were applied as reflective foliar coating, at privet farm (Dina farms about $80 \mathrm{~km}$ north of Cairo "Alexandria desert road" during 2016 and 2017 successive seasons on 6 - year old trees Baldy mandarin (Citrus reticulata Blanco), budded on sour orange rootstock under drip irrigation system. Twenty seven trees were selected at similar in growth vigor and fruiting, free from any visual infections and received regularly the recommended horticultural practices. Each treatment was applied into three replicates with 3 trees/replicate. The treatments were as follow:

1- The control (trees were sprayed with water).

2- Spraying Kaolin 3\% (3 Kg/100 L.) twice at mid-June and the 1st of July.

3- Spraying Kaolin $6 \%(6 \mathrm{Kg} / 100 \mathrm{~L})$ at mid-June.

Each tree received individually about ten liters of spraying solution "till runoff". The experiment was arranged in a randomized complete block design. Furthermore, to evaluate the efficiency of the tested treatments on tree fruiting and fruit quality.

At harvest time (mid-January) for both seasons, yield and fruit quality were evaluated as follow:

\section{Tree yield:}

Fruits were gathered during the ripe stage "late of January" from each tree of various replicates and yield weight ( $\mathrm{kg} /$ tree) was estimated by multiplying the number of fruits with average fruit weight.

\section{Fruit quality:}

\section{a) Fruit physical properties:}

Twenty fruits from each tree under study were chosen for determining the following parameters:

- Fruit weight (g).

- Fruit size (ml).

- Fruit shape index $=$ fruit length $(\mathrm{cm}) /$ fruit diameter $(\mathrm{cm})$.

- Fruit bulb weight $(\mathrm{g})$.

- Fruit firmness $\left(\mathrm{g} / \mathrm{mm}^{2}\right)$. 


\section{b) Fruit chemical properties:}

- Total Soluble Solids (TSS) by using a hand refract meter.

- Total Acidity of fruit juice (as citric acid \%) by titration with 0.1 Normal sodium hydroxide with phenolphthalein reagent (A.O.A.C., 2005).

\section{Yoghurt manufacturing:}

Fresh mandarin fruits were washed, peeled and cut into very small pieces with the disposal of the seed, then added as a puree to buffalo milk (14.88 \% T.S, $5 \%$ Fat), obtained from the Dairy Science Department, Faculty of Agriculture, Cairo University, for preparing the following treatments:

a) Yoghurt with $8 \%$ mandarin (the control)

b) Yoghurt with $12 \%$ mandarin (the control)

c) Yoghurt with $8 \%$ mandarin treated by Kaolin 3\% twice

d) Yoghurt with $8 \%$ mandarin treated by Kaolin $6 \%$

e) Yoghurt with $12 \%$ mandarin treated by Kaolin 3\% twice

f) Yoghurt with 12\% mandarin treated by Kaolin $6 \%$.

The yoghurt was manufactured according to the protocol proposed by Tamime and Robinson (1999) with some modification as shown in Fig (1).

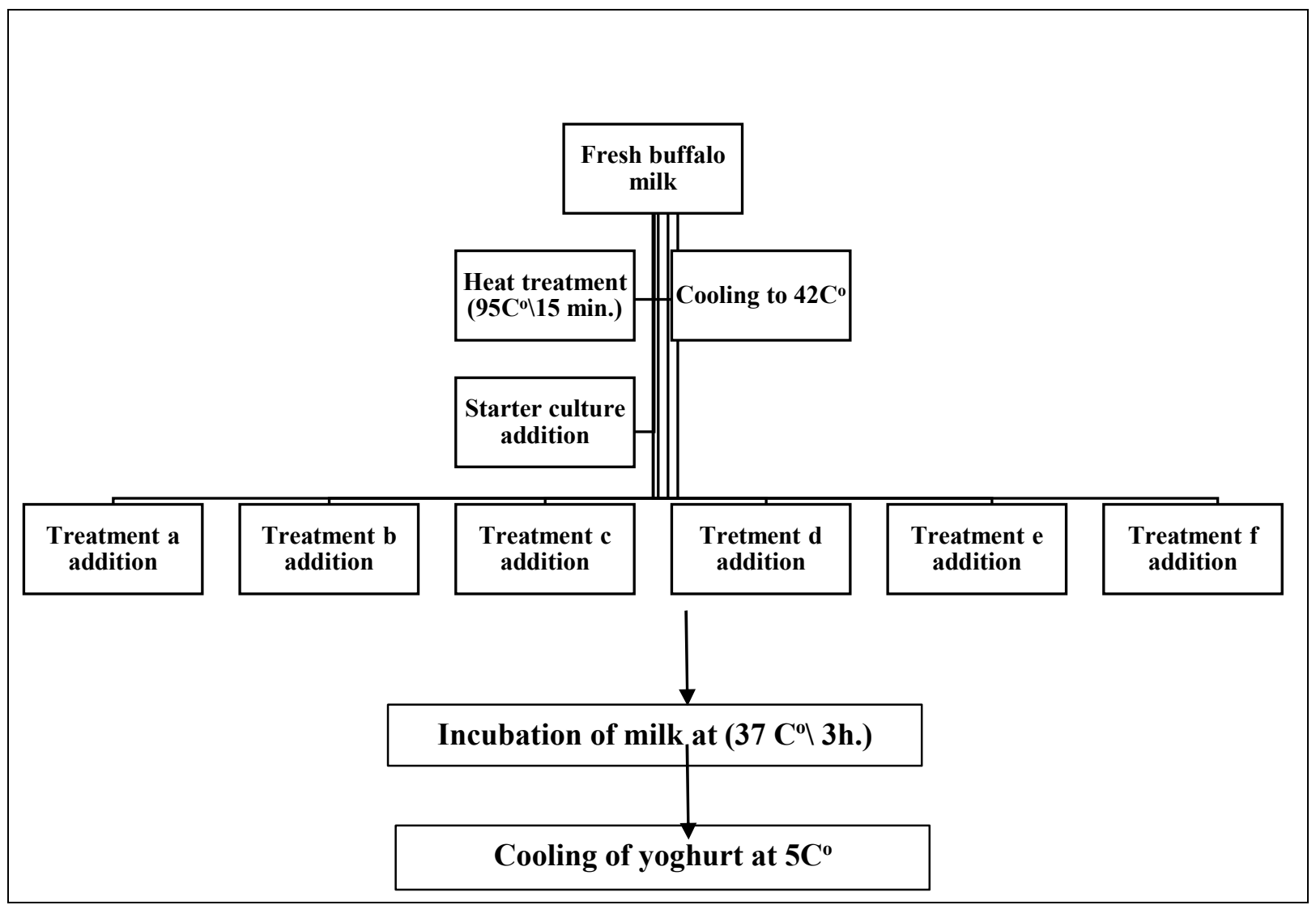

Fig. 1: Technological process of yoghurt samples with mandarin treated by anti-heat stress treatments Yoghurt samples were stored for 10 days at $5{ }^{\circ} \mathrm{C}+0.5^{\circ} \mathrm{C}$.

\section{Chemical analysis of yoghurt:}

Total solids (TS), Protein, Fats, Titratable Acidity and $\mathrm{pH}$ values of milk and yoghurt were determined according to the method described by A.O.A.C., (2005).

\section{Microbiological analysis of yoghurt:}

Testing and quantification of Total count and Yeast \& Mold was done according to standard methods for examination dairy products. texture profile of PCS was measured as described by Bourne (1982) using an Instron Universal Testing Machine model 1195, Stable Micro System (SMS) Ltd., Godalming, UK. 


\section{Rheological characteristics of yoghurt:}

Texture profile of PCS was measured as described by Bourne (1982) using Instron Universal Testing Machine model 1195, Stable Micro System (SMS) Ltd. Godalming, UK.

\section{Sensory Evaluation of yoghurt:}

Fresh set and flavored yoghurt from the different treatments were evaluated for their sensory attributes by ten well-trained members of the staff of the Food Technology Research Institute. The panelists were judged the samples for appearance(out of 10 points), flavor (out of 50 points) ,Body \&texture (out of 30 points) and color (out of 10 points) as described by El-Etriby et al. (1997).

\section{Statistical Analysis:}

Collected Data were subjected to analysis of variance and means were compared using LSD test at 5\% level according to Snedecor and Cochran (1980).

\section{Results and Discussion}

\section{Tree yield:}

It was obvious from data in Fig. (2), that all kaolin treatments "as anti-heat stress" increased the fruit yield / per tree $(\mathrm{kg})$ for both seasons in compared to the control treatment respectively. Moreover, spraying Kaolin $6 \%$ gave the highest values of fruit $(\mathrm{Kg}) /$ tree $(84.18 \& 57.83 \mathrm{Kg})$ when compared to the untreated trees $(72.88 \& 41.22 \mathrm{Kg})$ for both seasons. In addition, spraying Kaolin $3 \%$ twice increased the yield per tree $(82.16$ \& $49.39 \mathrm{Kg}$.) in compared to the control. Herein, kaolin treatments improve the tree fruit yield and reducing the fruit losses percentage.

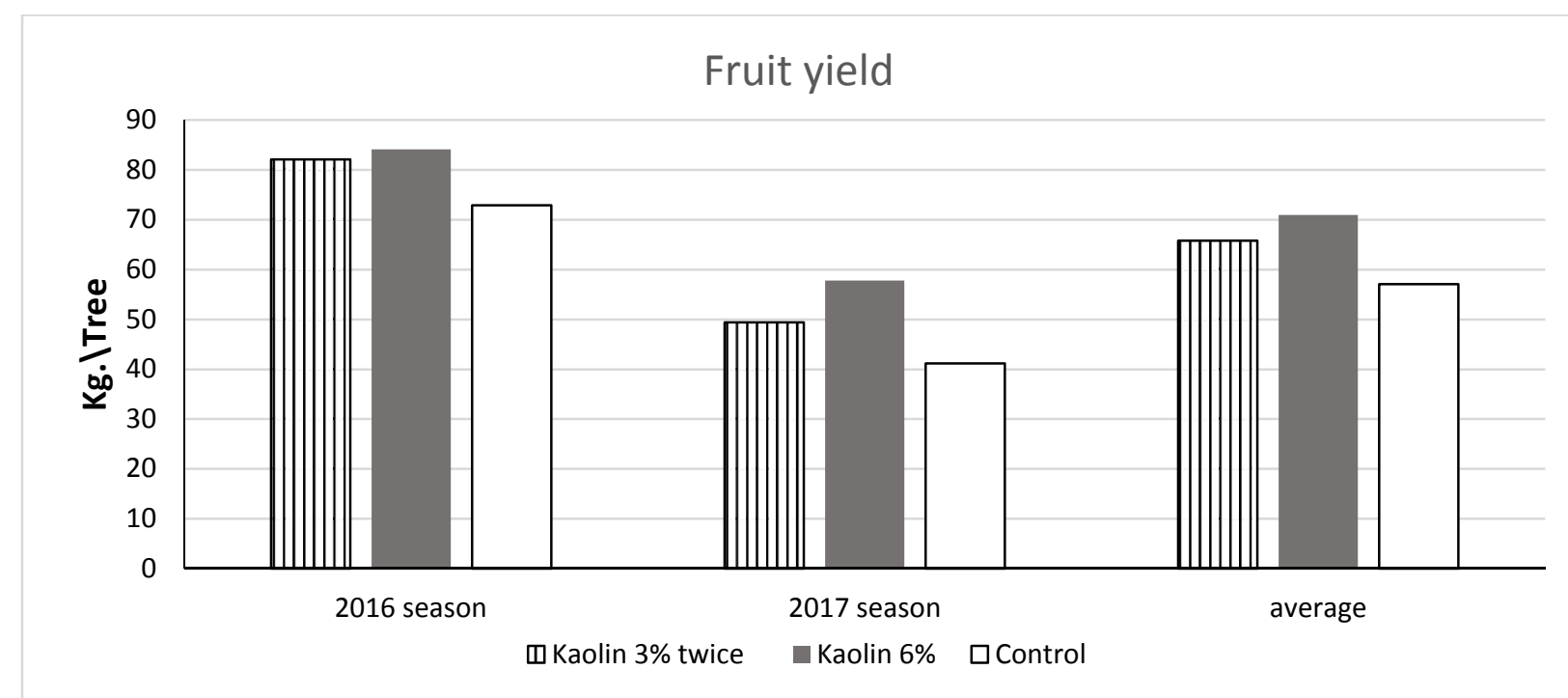

Fig. 2: Effect of Kaolin clay applications as anti-heat stress on yield / tree (Kg) of Baldy Mandarin trees during 2017 and 2018 seasons.

\section{Fruit quality:}

\section{a)Fruit physical properties:}

Effect of Kaolinite treatments on baldy mandarin fruit physical characteristics were expressed as: fruit( weight, size, shape index, pulp weight), data in table (1) illustrated that Kaolinite treatments significantly increased both fruit weight and size in the two studied seasons and decreased fruit shape index in compared to the control treatment. Also, Kaolin at 6\% conc., treatment gave the highest fruit weight (gm.) in both seasons (141.22 \&142.50), respectively. Whereas, Kaolin 3\% treatment caused a significant increase (135.2 \&138.6) in comparison with the control treatment (125.22 \&125.90) .Moreover, that increase was significantly less than Kaolin $6 \%$ treatment. 
In the same line, fruit size (ml.) were 157.67, 146.98 and 135.25 with Kaolin 6\%, Kaolin 3\% and control treatments in the $1^{\text {st }}$ season, respectively. While in the $2^{\text {nd }}$ season it was $152.98,142.43$ and 127.38 , respectively. In contrary, it's clear that Kaolin $6 \%$ and $3 \%$ conc., gave the lowest shape index " $0.904 \& 0.881$ " in compared to the control treatment 0. " 0.846 ". While in $2^{\text {nd }}$ season it were $0.891,0.879$ and 0.848 , respectively

On the other hand application of Kaolin $6 \%$ caused a significant increase in fruit pulp weight which were (96.08 and $96.67 \mathrm{gm})$ in the $1^{\text {st }}$ and $2^{\text {nd }}$ seasons respectively in compared to Kaolin $3 \%$ and the control treatments. Also, Kaolin 3\% treatment have significantly increased the pulp weight than the control treatment. As for fruit firmness, Kaolin $6 \%$ application gave the highest values " 42.89 and $44.67 \mathrm{~g} / \mathrm{mm}^{2)}$ in $1^{\text {st }}$ and $2^{\text {nd }}$ seasons, respect., followed by Kaolin $3 \%$ conc., (37.56 and 38.11 $\left.\mathrm{g} / \mathrm{mm}^{2}\right)$ respectively, and the control treatment $\left(34.89\right.$ and $\left.33.11 \mathrm{~g} / \mathrm{mm}^{2}\right)$ respectively.

Table 1: Effect of Kaolin clay applications as anti-heat stress on some fruit physical characteristics during the $1^{\text {st }} \& 2^{\text {nd }}$ seasons.

\begin{tabular}{|c|c|c|c|c|c|}
\hline Treatments & $\begin{array}{l}\text { Fruit weight } \\
\text { (g) }\end{array}$ & $\begin{array}{c}\text { Fruit size } \\
(\mathrm{ml} .)\end{array}$ & $\begin{array}{l}\text { Shape } \\
\text { index }\end{array}$ & $\begin{array}{c}\text { Pulp weight } \\
\text { (g) }\end{array}$ & $\begin{array}{c}\text { Firmness } \\
\left(\mathrm{g} / \mathrm{mm}^{2}\right)\end{array}$ \\
\hline \multicolumn{6}{|c|}{ The $1^{\text {st }}$ season } \\
\hline Kaolin 3\% twice & $135.20 \mathrm{~B}$ & 146.98 B & $0.881 \mathrm{~B}$ & $89.84 \mathrm{~B}$ & $37.56 \mathrm{~B}$ \\
\hline Kaolin 6\% & $141.22 \mathrm{~A}$ & $157.67 \mathrm{~A}$ & $0.846 \mathrm{C}$ & $96.08 \mathrm{~A}$ & $42.89 \mathrm{~A}$ \\
\hline Control & $125.22 \mathrm{C}$ & $135.25 \mathrm{C}$ & $0.904 \mathrm{~A}$ & $82.07 \mathrm{C}$ & $34.89 \mathrm{C}$ \\
\hline L.S.D (0.05) & 5.98 & 10.45 & 0.021 & 6.12 & 2.37 \\
\hline \multicolumn{6}{|c|}{ The $2^{\text {nd }}$ season } \\
\hline Kaolin 3\% twice & $138.60 \mathrm{~B}$ & $142.43 \mathrm{~B}$ & $0.879 \mathrm{~B}$ & $92.06 \mathrm{~B}$ & $38.11 \mathrm{~B}$ \\
\hline Kaolin 6\% & $142.50 \mathrm{~A}$ & $152.98 \mathrm{~A}$ & $0.848 \mathrm{C}$ & $96.67 \mathrm{~A}$ & $44.67 \mathrm{~A}$ \\
\hline Control & $125.90 \mathrm{C}$ & $127.38 \mathrm{C}$ & $0.891 \mathrm{~A}$ & $82.80 \mathrm{C}$ & $33.11 \mathrm{C}$ \\
\hline L.S.D (0.05) & 3.4 & 9.35 & 0.011 & 4.32 & 4.65 \\
\hline
\end{tabular}

Means with same capital letter did not differ significantly.

Present study cleared that, both Kaolin treatments caused an increase in fruit yield combined by similar increase with fruit weight and size, such finding was in the same line with those obtained by Myhob et al. (1996), Jifon and Syvertsen, (2003) and Tsai et al. (2013), they found that an increases in fruit weight and size due to anti sunburn applications reduced water losses from fruit peel during fruit development stage (from June to August) which increased the peel flexibility. Also, Jifon and Syvertsen, (2003) whom illustrated that when grapefruit leaves treated with kaolin film particles caused an increase in stomatal gas exchange of leaves, $\mathrm{Co}_{2}$ assimilation rates and water use efficiency. This findings will be reflected on fruit pulp weight and firmness (Spiegel-Roy and Goldschmidt, 1996). Therefore, postharvest reduction in citrus fruit firmness is largely due to loss of water, mainly from the peel (Spiegel-Roy and Goldschmidt, 1996), thus, any treatment can be reduced moisture loss and retain fruit firmness (Kawada and Albrigo, 1979).

\section{b) Fruit Chemical properties}

As for, some chemical properties of treated baldy mandarin fruits in compared to the control, in terms of Total Soluble Solids TSS, Acidity, Total Soluble Solids to Acid Ratio TSS/TA R., total sugar, fibers and proteins. Data in Table (2) cleared that, Kaolin applications at $6 \%$ conc., treatment gave the highest TSS and Acidity percentages respectively, followed by kaolin applications at 3\% concentration twice then the control treatment during both studied seasons. Whereas, TSS\% were $\left(11.83,12.33 \& 10.20 \%\right.$ respectively, in the $1^{\text {st }}$ season, while it were $11.96,12.78$ and $10,87 \%$, respectively, in the $2^{\text {nd }}$ season. Acidity percentages were $1.36,1.46$ and $1.29 \%$ and $1.33,1.48$ and $1.24 \%$ respectively, in both seasons. As for, TSS/TA ratio, kaolin 3\% twice had the highest TSS/TA ratio followed by kaolin $6 \%$ then control treatments. In spite of, both Kaolin treatments were higher values than control treatment, but there were no significant differences between them on total sugar $\%$. Fiber contents was significantly higher with kaolin 3\% conc., treatment followed by kaolin $6 \%$ conc., then control treatments. On the other hand, kaolin at $6 \%$ conc., treatment gave the highest proteins contents followed by kaolin at $3 \%$ conc., then the control treatments. 
Table 2: Effect of Kaolin clay applications as anti-heat stress on chemical composition of mandarin fruit s during the $1^{\text {st }} \& 2^{\text {nd }}$ seasons.

\begin{tabular}{|c|c|c|c|c|c|c|}
\hline Treatments & $\begin{array}{l}\text { TSS } \\
(\%)\end{array}$ & $\begin{array}{c}\text { Acidity } \\
(\%)\end{array}$ & $\begin{array}{c}\text { TSS/TA } \\
\text { Ratio }\end{array}$ & $\begin{array}{c}\text { Total } \\
\text { sugar } \\
(\%)\end{array}$ & $\begin{array}{c}\text { Fiber } \\
(\%)\end{array}$ & $\begin{array}{c}\text { Protein } \\
(\%)\end{array}$ \\
\hline \multicolumn{7}{|c|}{$1^{\text {st }}$ season $^{\text {a }}$} \\
\hline Kaolin 3\% twice & $11.83 \mathrm{~b}$ & $1.36 \mathrm{~b}$ & $8.70 \mathrm{a}$ & $7.75 \mathrm{a}$ & $0.73 \mathrm{a}$ & $1.75 \mathrm{~b}$ \\
\hline Kaolin 6\% & $12.33 \mathrm{a}$ & $1.46 \mathrm{a}$ & $8.45 \mathrm{~b}$ & $8.10 \mathrm{a}$ & $0.66 \mathrm{~b}$ & $1.86 \mathrm{a}$ \\
\hline Control & $10.20 \mathrm{c}$ & $1.29 \mathrm{c}$ & $7.91 \mathrm{c}$ & $6.87 \mathrm{~b}$ & $0.62 \mathrm{c}$ & $1.20 \mathrm{c}$ \\
\hline L.S.D (0.05) & 0.4 & 0.09 & 0.24 & 0.55 & 0.04 & 0.1 \\
\hline \multicolumn{7}{|c|}{$2^{\text {nd }} \operatorname{season}^{a}$} \\
\hline Kaolin 3\% twice & $11.96 \mathrm{~b}$ & $1.33 \mathrm{~b}$ & $8.99 \mathrm{a}$ & $7.92 \mathrm{a}$ & $0.77 \mathrm{a}$ & $1.80 \mathrm{~b}$ \\
\hline Kaolin 6\% & $12.78 \mathrm{a}$ & $1.48 \mathrm{a}$ & $8.64 \mathrm{~b}$ & $8.22 \mathrm{a}$ & $0.69 \mathrm{~b}$ & $1.95 \mathrm{a}$ \\
\hline Control & $10.87 \mathrm{c}$ & $1.24 \mathrm{c}$ & $8.17 \mathrm{c}$ & $6.92 \mathrm{~b}$ & $0.66 \mathrm{c}$ & $1.25 \mathrm{c}$ \\
\hline L.S.D (0.05) & 0.7 & 0.08 & 0.31 & 0.5 & 0.02 & 0.12 \\
\hline
\end{tabular}

${ }^{\mathrm{a}}$ Means with same capital letter did not differ significantly.

These results are harmony with those obtained by Ennab et al. (2017) and El-Tanany et al. (2019) whom showed that foliar application of kaolin as treatment for sunburn in baldy mandarin caused an increase in TSS, acidity and TSS/TA Ratio. Moreover, Chabbal et al. (2014) using of Kaolin applications to control sunburn in Okitsu mandarin, found that an increase of tested chemical properties may be due to the increase of photosynthesis which lead to creation more sugar, fibers and proteins .

\section{Chemical Composition of Yoghurt with mandarin}

Results in (Table 3) declared that protein increased in fruits from trees treated by Kaolin $6 \%$. The changes of composition in different yoghurt as affected by addition of mandarin treated by Kaolin $3 \%$ twice and Kaolin $6 \%$ were presented in (Table 3). The total solids (TS) was higher in yoghurt with mandarin treated by Kaolin 6\% and Kaolin 3\% twice, total solids of control yoghurt was 16.08 and 16.18 while total solids was $16.36,16.38,16.45$ and 16.77 in yoghurt with mandarin treated by Kaolin $6 \%$ and Kaolin 3\% twice. The nutritional value of yoghurt with mandarin was better in terms of fat, protein and ash content, these results was due to the composition of mandarin treated by kaolin, screen. The acidity of yoghurt were decreased, it was reported that, the high rate of production of lactic acid in yoghurt was observed at the initial 12 days due to the high bacterial metabolic activity with the consumption of lactose (Beal, 1999).

In general, the $\mathrm{pH}$ was lower in yoghurts fortified with control mandarin when compared with mandarin with kaolin, screen. Lee and Lucey (2010) mentioned that, the increased solids content in yoghurt milk as a result of fortification also creates increased buffering that requires additional antiheat stress treatments development by starter culture to achieve a similar $\mathrm{pH}$ target .The increasing of $\mathrm{pH}$ values of yoghurt fortified with mandarin ranged from 4.62 to 4.89 . Ash increased from 0.77 to $0.88 \%$.

Table 3: Effect of Kaolin clay applications as anti-heat stress on chemical composition of yoghurt.

\begin{tabular}{ccccccc}
\hline Samples & $\begin{array}{c}\text { T.S } \\
\mathbf{\%}\end{array}$ & $\begin{array}{c}\text { Protein } \\
(\mathbf{\% )}\end{array}$ & $\begin{array}{c}\text { Fat } \\
\mathbf{( \% )}\end{array}$ & $\begin{array}{c}\text { Ash } \\
\mathbf{( \% )}\end{array}$ & $\begin{array}{c}\text { Titratable } \\
\text { acidity }\end{array}$ & pH \\
\hline $\mathbf{A}$ & 16.08 & 4.14 & 3.23 & 0.77 & 1.77 & 4.62 \\
$\mathbf{B}$ & 16.18 & 4.15 & 3.23 & 0.80 & 1.77 & 4.62 \\
$\mathbf{C}$ & 16.36 & 4.26 & 3.46 & 0.78 & 1.73 & 4.75 \\
$\mathbf{D}$ & 16.68 & 4.33 & 3.37 & 0.86 & 1.65 & 4.80 \\
$\mathbf{E}$ & 16.45 & 4.27 & 3.55 & 0.86 & 1.68 & 4.82 \\
$\mathbf{F}$ & 16.77 & 4.34 & 3.69 & 0.88 & 1.60 & 4.89 \\
\hline
\end{tabular}

\section{Microbiological analysis}

Microbiological analysis of yoghurt with adding mandarin (Table 4) showed that, total count increased during storage periods, samples A and B had the higher total count than the other treatments. It can be seen clearly from Table 4 that yeast and mold counts increased progressively during storage. Çon et al. (1996) found that, the high yeast and mold count could be attributed to 
contamination from air, the fruit marmalade, molasses and the 1 day old culture used for yogurt manufacture. Treatments $\mathrm{E}$ and $\mathrm{F}$ had the lowest total count and yeast \& mold than all treatments during storage periods; these results may due to decreasing of acidity and the effect the percentage of anti-heat stress treatments in mandarin.

Table 4: Effect of Kaolin clay applications as anti-heat stress on Microbiological analysis of yoghurt with adding mandarin.

\begin{tabular}{lccccccccccccc}
\hline Parameters & \multicolumn{2}{c}{ A } & \multicolumn{1}{c}{ B } & \multicolumn{1}{c}{ C } & \multicolumn{1}{c}{ D } & \multicolumn{2}{c}{ E } & \multicolumn{3}{c}{ F } \\
\hline $\begin{array}{l}\text { Storage } \\
\text { periods(days) }\end{array}$ & 5 & 10 & 5 & 10 & 5 & 10 & 5 & 10 & 5 & 10 & 5 & 10 \\
Total count $\left(\log ^{10}\right)$ & 8.18 & 8.48 & 8.20 & 8.52 & 7.31 & 7.44 & 7.32 & 7.42 & 7.13 & 7.20 & 7.06 & 7.12 \\
$\begin{array}{l}\text { Molds } \\
\text { \&Yeast }\left(\log ^{10}\right)\end{array}$ & 3.65 & 4.22 & 3.66 & 4.25 & 3.11 & 3.44 & 3.14 & 3.46 & 2.34 & 2.65 & 2.19 & 2.50 \\
\hline
\end{tabular}

\section{Rheological characteristics of yoghurt}

Yoghurt made with mandarin treated by anti-heat stress treatments (Table 5), it was observed the differences between treatments of the yogurts fortified with the different dairy ingredients. Results indicated that, except of the springiness criterion, other texture parameters, namely hardness, cohesiveness, gumminess and chewiness exhibited proportionally higher values. The texture of samples treated by salicylic acid changed, these observation may due to increasing of total solids while, springiness of yoghurt samples behaved opposite trend. Similar findings were reported by Pollard et al. (2003).

Table 5: Changes in rheological characteristics of yoghurt with adding mandarin

\begin{tabular}{cccccc}
\hline Samples & $\begin{array}{c}\text { Hardiness } \\
(\mathbf{N})\end{array}$ & $\begin{array}{c}\text { Chewiness } \\
(\mathbf{N} / \mathbf{m})\end{array}$ & $\begin{array}{c}\text { Cohesiveness } \\
(-)\end{array}$ & $\begin{array}{c}\text { Springiness } \\
(\mathbf{m m})\end{array}$ & $\begin{array}{c}\text { Gumminess } \\
(\mathbf{N})\end{array}$ \\
\hline $\mathbf{A}$ & 0.7 & 1.97 & 0.24 & 12.06 & 0.2 \\
$\mathbf{B}$ & 0.7 & 1.69 & 0.27 & 12.10 & 0.2 \\
$\mathbf{C}$ & 0.9 & 2.52 & 0.32 & 11.35 & 0.3 \\
$\mathbf{D}$ & 0.9 & 2.55 & 0.38 & 11.15 & 0.4 \\
$\mathbf{E}$ & 1.8 & 3.76 & 0.52 & 11.59 & 0.4 \\
$\mathbf{F}$ & 1.9 & 4.21 & 0.24 & 11.08 & 0.4 \\
\hline
\end{tabular}

$\mathrm{N}$ : Newton m: meter millimeter

\section{Sensory Evaluation}

Sensory attributes were evaluated as flavor, texture, color and overall acceptability. The results for the experimental yogurts are given in (Table 7). The yogurt samples with mandarin containing anti-heat stress treatments had a higher scores of overall acceptability compared with the other treatments. These results may due to the physical characteristics of mandarin treated by anti-heat stress treatments.

Table 7: Sensory evaluation of yoghurt with adding mandarin.

\begin{tabular}{ccccccc}
\hline Sample & $\begin{array}{c}\text { Storage periods } \\
\text { (days) }\end{array}$ & $\begin{array}{c}\text { Appearance } \\
(\mathbf{1 0})\end{array}$ & $\begin{array}{c}\text { Flavor } \\
\mathbf{( 5 0 )}\end{array}$ & $\begin{array}{c}\text { Body \& Texture } \\
\mathbf{( 3 0 )}\end{array}$ & $\begin{array}{c}\text { Color } \\
(\mathbf{1 0 )}\end{array}$ & $\begin{array}{c}\text { Overall } \\
\text { acceptability }\end{array}$ \\
\hline \multirow{2}{*}{$\mathbf{A}$} & 5 & 8 & 46 & 27 & 9 & 90 \\
& 10 & 6 & 42 & 26 & 6 & 80 \\
\hline \multirow{2}{*}{ B } & 5 & 9 & 47 & 27 & 8 & 91 \\
& 10 & 7 & 41 & 25 & 6 & 79 \\
\hline \multirow{2}{*}{$\mathbf{C}$} & 5 & 9 & 47 & 27 & 9 & 92 \\
& 10 & 8 & 44 & 26 & 7 & 85 \\
\hline \multirow{2}{*}{$\mathbf{D}$} & 5 & 9 & 47 & 27 & 9 & 92 \\
& 10 & 8 & 45 & 27 & 7 & 87 \\
\hline \multirow{2}{*}{$\mathbf{E}$} & 5 & 9 & 48 & 28 & 9 & 94 \\
& 10 & 8 & 46 & 26 & 7 & 87 \\
F & 5 & 9 & 49 & 29 & 8 & 95 \\
& 10 & 8 & 46 & 28 & 7 & 89 \\
\hline
\end{tabular}


Texture of yoghurt is influenced by various factors such as quality and composition of milk and its protein and fat content, heat treatment, combination of lactic acid bacteria used, acidification rate, and storage time (Sodini et al., 2004).

Similarly, sensory evaluation scores on the flavor, the body and texture, and the color and appearance of the yogurts fortified with casein hydrolysis decreased by storage time (Zhao et al., 2006). It was observed that, samples $E$ and $F$ had the highest scores of sensory evaluation while, samples A and B had the lowest scores.

\section{Conclusion}

It could be concluded that Kaolin applications as anti-heat stress treatments enhance fruit yield and fruit quality of baldy mandarin fruits, especially at $6 \%$ conc. Moreover, Mandarins (Citrus reticulate) fruits treated by Kaolin clay (organic material) as anti-heat stress treatments can be used as a functional ingredient in yoghurt due to its flavor, natural antioxidant, fibers and pectin content. In addition, it consider a nutritive constitute and health promoting characteristics will be improved the rheological characteristics and the total acceptability of yoghurt. And it can be used successfully in making functional yoghurt of acceptable sensory. Finally, it can be recommended that spraying of Mandarin (Citrus reticulate) trees by Kaolin clay (organic material) as anti-heat stress treatments at $6 \%$ conc., to reduce the injury effect of sunburn which can be used in the manufacture of yoghurt .

\section{References}

A.O.A.C., 2005. Official Methods of Analysis of the Association of the Analytical Chemists. Washington, USA.

Abeysinghe, D., X. Li, C. Sun, W. Zhang, C. Zhou, K. Chen, 2007. Bioactive compounds and antioxidant capacities in different edible tissues of citrus fruit of four species. Food Chem., 104:1338-1344.

Ahmed, F.F., M.M.A. Abada and H.M.A. El-Hameed, 2012. Alleviating the adverse effect of sunburn on yield and colouration of Red Roomy grapevines by spraying calcium carbonate and sunscreen compounds. Proceedings of the Minia Ist International Conference for Agriculture and Irrigation in the Nile Basin Countries, March 26-29, Minia, Egypt, pp: 84-89.

Azizi, A., H. Hokmabadi, S. Piri and V. Rabie, 2013. Effect of kaolin application on water stress in pistachio cv. Ohadi. Journal of Nuts. 4 (4): 9-14

Beal, M.F., 1999. Mitochondria, N.O. and neurodegeneration. Biochem. Soc. Symp., 66, 43-54.

Bourne, M.C., 1982. Texture profile analysis. Food Technology, 32, 62-66,72.

Çon, A. H., S. Çakmakc1, A. Çağlar, H. Y. Gökalp, 1996. Effects of different fruits and storage periods on microbiological qualities of fruit-flavored yogurt produced in Turkey. J. Food Prot., 59:402-406.

Chabbal, M.D., A.B. Piccoli, G.C. Martinez, M.M. Avanza, S.M. Mazza and V.A. Rodriguez, 2014. Kaolin applications to control sunburn in 'Okitsu' mandarin. Cultivos Tropicales, 35(1): 5056.

De Ancos, B., A. Cilla, R. Barbera, S. C. anchez-Moreno, M.P. Cano, 2017. Influence of orange cultivar and mandarin postharvest storage on polyphenols, ascorbic acid and antioxidant activity during gastrointestinal digestion. Food Chem., 225:114-24.

Ebrahiem Asmaa, A., 2012. Alleviating the adverse effects of sunburn on the production of Red Roomy grapevines growing under Minia region conditions. Minia J. Agric. Res. Dev., 32: $165-175$.

El-Etriby, H.M., R.T. El-Darouty, and A.H. Zaghloul, 1997. Physicochemical and bacteriological studies on mango yoghurt manufacture from ultrafiltrated milk retentat using glucodeltalactone (GDL). Egyptian J. Dairy Sci., 25:349.

El-Khawaga, A. S. and A. E .Mansour, 2014. Enhancing the efficiency of irrigation water use by using some antitranspirants in Wonderful pomegranate orchards. Middle East J. Agric. Res., 3 (3): 694- 700.

El-Tanany, M.M., A.M.A. Kheder and H. R. Abdallah, 2019. Effect of kaolin applications on fruit sunburn, yield and fruit quality of balady mandarin (Citrus reticulata, Blanco) 
Ennab, H. A., S. A. El-Sayed and M. M. Abo El-Enin, 2017. Effect of kaolin applications on fruit sunburn, yield and fruit quality of Balady mandarin (Citrus reticulata, Blanco). Menoufia J. Plant Prod., 2: 129-138.

Glenn, D.M., 2009. Particle film mechanisms of action that reduce the effect of environmental stress in 'Empire' apple. J. Amer. Soc. Hort. Sci., 134:314-321.

Hassan, M.M. and S.A. Seif, 1997. Water use of some fruit tree species. Egypt J. Hort., 24: 131-131.

Kawada, K., and L.G. Albrigo. 1979. Effects of film packaging, in-carton air filters, and storage temperatures on the keeping quality of florida grapefruit Proc. Fla. Sta. Hort. Soc., 92: 209212.

Jifon, J.L. and J.P. Syvertsen, 2003. Kaolin particle film application can increase photosynthesis and water use efficiency of 'Ruby Red' grapefruit leaves. J. Amer. Soc. Hort. Sci., 128, 107-112.

Lee, W. J., and J. A. Lucey, 2010. Formation and physical properties of yoghurt. Asian-Australasian Journal of Animal Science, 23: 1127.

Lourens, A., and C. B. Viljoen, 2001.Yoghurt as probiotic carrier food, in "International Daiary Journal" No.Vol.11.

Minessy, F.A., T.A.A. Nasr, and M.Y. El-Shurafa, 1969. Citrus fruit temperature in relation to sunburn .Proceeding of the Conference on tropical and subtropical fruits. Londen School of pharmacy, Brunswick Square, 245-252.

Myhob, M.A., L.F. Guindy, and S.E. Salem, 1996. Influence of sunburn on Balady mandarin fruits and its control. Bull. Fac. Agric. Univ. Cairo, 47, 457- 470.

Prakash, M. and K. Ramachandran, 2000. Effects of chemical ameliorants in brinjal (Solanum melongena L.) under moisture stress conditions. Journal of Agronomy and Crop Science, 185: 237-239

Pollard, A., F. Sherkat, M. G. Seuret and A. L. Halmos, 2003. Textural changes of natural cheddar cheese during process. J. Food Sci., 68, 2001-2016.

Saleh, M.M.S., and M. El-Ashry-Soad, 2006. Effect of some antitranspirants on leaf mineral content, fruit set, yield and fruit quality of Washington navel and Succary orange trees. J. Applied Sci. Res., 2: 486-490.

Snedecor, G.W. and W.G. Cochron, 1980. "Statistical Methods", 7th ed. Iowa State University Press, Ames, $507 \mathrm{p}$.

Sodini, I., F. Remeuf, S. Haddad, and G. Corrieu, 2004. The relative effect of milk base, starter and process on yoghurt texture: A review. Crit. Rev. Food Sci. Nutr., 44: 113-137

Sophocleous, M., 2004. Global and regional water availability and demand: Prospects for the future. Nat. Resour. Res., 13: 61-75.

Spiegel-Roy, P., and E.E. Goldschmidt, 1996. Biology of citrus. Cambridge University Press, Cambridge, UK.

Tamime, A. Y., and R. K. Robinson, 1999. Yoghurt Science and Technology, London, UK: Woodhead publishing, $598 \mathrm{pp}$.

Tsai, M.S., T.C Lee, and P.T. Chang, 2013. Comparison of paper bags, calcium carbonate, and shade nets for sunscald protection in 'Murcott' tangor fruit. Hort. Technology, 23 (5), 659-667.

Verreynne, S., and S.V. Merwe, 2011. Sunburn reduction on Miho Wase Satsuma mandarin. South Africa Fruit Journal, 10 (2): 5255.

Yahaya S., S. S. Jikan, N. A. Badarulzaman and A.D. Adamu, 2017. Chemical Composition and Particle Size Analysis of Kaolin. Traektoriâ Nauki = Path of Science. Vol. 3, No 10

Zaky, Manal, A., A. Amal El-Baowab and A. Mohamed Shaimaa, 2018. Impact of spraying some chemical substances on controlling sunburn of Balady Mandarin fruits. Egypt. J. Hort., 45 (2): 229-236.

Zhao, Q.Z., J.S. Wang, M.M. Zhao, Y.M. Jiang, and C. Chun, 2006. Effect of casein hydrolysates on yoghurt fermentation and texture properties during storage. Food Technol. Biotechnol. 44: 429-434. 